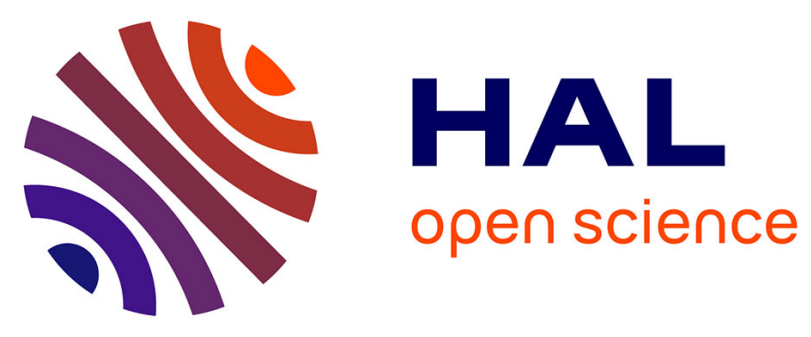

\title{
Measurement of the absolute gamma-ray emission intensities from the decay of ${ }^{147} \mathrm{Nd}$
}

\author{
Mark Kellett, Laurent Vio, Christophe Bobin, Laurine Brondeau, Mikael \\ Cardot-Martin, Hélène Isnard, Lacour Daniel, Marie-Christine Lépy, Valérie \\ Lourenço, M. Marie, et al.
}

\section{To cite this version:}

Mark Kellett, Laurent Vio, Christophe Bobin, Laurine Brondeau, Mikael Cardot-Martin, et al.. Measurement of the absolute gamma-ray emission intensities from the decay of ${ }^{147} \mathrm{Nd}$. ICRM 2019 - $22 \mathrm{nd}$ International Conference on Radionuclide Metrology and its Applications, International Committee for Radionuclide Metrology (ICRM); University of Salamanca, May 2019, Salamanca, Spain. pp.53. cea-03044618

\section{HAL Id: cea-03044618 https: / hal-cea.archives-ouvertes.fr/cea-03044618}

Submitted on 7 Dec 2020

HAL is a multi-disciplinary open access archive for the deposit and dissemination of scientific research documents, whether they are published or not. The documents may come from teaching and research institutions in France or abroad, or from public or private research centers.
L'archive ouverte pluridisciplinaire HAL, est destinée au dépôt et à la diffusion de documents scientifiques de niveau recherche, publiés ou non, émanant des établissements d'enseignement et de recherche français ou étrangers, des laboratoires publics ou privés. 


\title{
MEASUREMENT OF THE ABSOLUTE GAMMA-RAY EMISSION INTENSITIES FROM THE DECAY OF ${ }^{147} \mathrm{Nd}$
}

\author{
M.A. Kellett ${ }^{1}$, L. Vio ${ }^{2}$, C. Bobin ${ }^{1}$, L. Brondeau ${ }^{1}$, M. Cardot-Martin ${ }^{1}$, H. Isnard ${ }^{2}$,

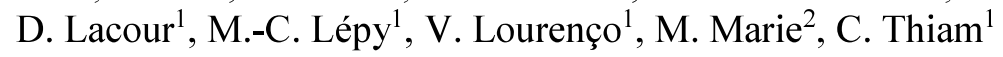 \\ ${ }^{1}$ CEA, LIST, Laboratoire National Henri Becquerel (LNE-LNHB), Bât. 602 PC111, CEA-Saclay, 91191 Gif- \\ sur-Yvette Cedex, France \\ ${ }^{2} C E A, D E N$, Laboratoire de développement Analytique Nucléaire Isotopique et Elémentaire (LANIE), Bât. \\ 391 PC33, CEA-Saclay 91191 Gif-sur-Yvette Cedex, France \\ $\begin{array}{ll}\text { Keywords: } & \begin{array}{l}\text { Absolute } \gamma \text {-ray emission intensities, }{ }^{147} \mathrm{Nd}, \mathrm{HPGe} \text { detector, } 4 \pi \beta-\gamma \text { coincidence, } \\ 4 \pi \gamma \text { counting, Uncertainty budget, Radionuclide metrology }\end{array}\end{array}$
}

\begin{abstract}
The 2011 Decay Data Evaluation Project (DDEP) evaluation for ${ }^{147} \mathrm{Nd}$ includes recommended absolute emission intensities for the two main gamma-rays at $91.105(2) \mathrm{keV}$ and 531.016 (22) $\mathrm{keV}$ of 0.284(18) and $0.127(9)$ respectively, i.e. with uncertainties of $6.3 \%$ and $7.1 \%$. These large uncertainties stem from inconsistencies in the published data and are unfit for modern purposes, since the production of ${ }^{147} \mathrm{Nd}$ is used as an important neutron flux dosimeter. Hence the LNE-LNHB has undertaken new absolute gamma-ray emission intensity measurements.

The ${ }^{147} \mathrm{Nd}$ source was produced at the TU Delft, Netherlands, during a one week irradiation in their reactor, using a sample enriched to $97.4 \%{ }^{146} \mathrm{Nd}$. An activity of $\sim 6 \mathrm{MBq}$ was received, following the irradiation of $\sim 150 \mu \mathrm{g}$ of ${ }^{146} \mathrm{Nd}$. The deposit was dissolved in $1 \mathrm{M} \mathrm{HCl}$ to prepare a $2 \mathrm{MBq} / \mathrm{g}$ solution from which the sources were produced.

In order to ensure as little interference as possible from the subsequent decay of the ${ }^{147} \mathrm{Pm}$ daughter, and any possible impurities, a separation was undertaken using High Performance Liquid Chromatography directly coupled with an Inductively Coupled Plasma Mass Spectrometry, by the Laboratoire de développement Analytique Nucléaire Isotopique et Élémentaire (LANIE) of CEA, which developed the necessary procedure.

Absolute activity measurements were performed using two techniques before and after separation: the $4 \pi \beta-\gamma$ coincidence method and the $4 \pi \gamma$ counting technique using a well-type NaI(Tl) detector. The gamma-ray intensities were measured using an N-type high-purity germanium (HPGe) detector with $100 \mathrm{~cm}^{3}$ germanium crystal equipped with a $500 \mu \mathrm{m}$ Be entrance window calibrated using standard point sources. Measurements were carried out before and after separation and give consistent results.

The results of these measurements will be presented, along with a full uncertainty budget, and their effect on the recommended data uncertainties will be discussed. For example, for the two main gammarays at $91.105(2) \mathrm{keV}$ and $531.016(22) \mathrm{keV}$, the absolute emissions intensities have now been measured as $0.2870(35)$ and $0.1311(13)$ respectively, i.e. with uncertainties of $1.2 \%$ and $1.0 \%$, far smaller than the current uncertainties on the evaluated data.
\end{abstract}

